\title{
Histopathological changes related to chemical contamination in Mytilus edulis from field and experimental conditions
}

\author{
M. Auffret \\ Pathology Laboratory, Faculty of Medicine, Université de Bretagne Occidentale, F-29283 Brest Cedex, France
}

\begin{abstract}
This comparative histopathological study, carried out at the GEEP Workshop, assesses tissue changes in mussels Mytilus edulis from a contaminated Norwegian fjord and from mesocosm basins where a contaminant gradient had been simulated. Parasitism by larval trematodes was observed in both circumstances, but was not related to contaminant levels. Mussels from the field exhibited granulocytomas in their interstitial tissues, with a greater incidence at polluted sites than at a reference site, suggesting that granulocytomas could be a consequence of chronic pollutant exposure. This pathological condition was not observed in experimentally treated mussels, which nevertheless had severe tissue alterations, especially in digestive tubules and gills, under exposure to high levels of a diesel oil and copper mixture. It is concluded that this type of histopathological analysis can provide useful information on the health of mussels, and that this information can be used successfully in the comparison of field samples.
\end{abstract}

\section{INTRODUCTION}

Pathology is now a standard part of environmental monitoring programmes on pollution effects (Yevich \& Barszcz 1976, Balouet \& Poder 1981, Couch 1985). Based on an easily reproducible technique, histopathological studies yield basic information on tissue disorders related to the general state of organisms, and assess the host's susceptibility to infectious diseases and parasitic infestation. Some of these parameters may serve as indicators of the effects of xenobiotic contamination in marine animals (Sindermann 1980). Among the diseases and pathological changes that can be measured in terms of prevalence and geographical distribution, it is essential to select parameters that are related to pollution, rather than other environmental stressors, in order to determine efficient tools for monitoring programmes (Sindermann et al. 1980).

The present study was undertaken both on field and experimentally exposed Mytilus edulis. Its aim was to ascertain the ability of tissue and organ changes, and the prevalence of parasitism and other diseases, to determine the effects of xenobiotics at various concentrations.

\section{MATERIAL AND METHODS}

Mytilus edulis were collected during August 1986 from field sites in Langesundfjord (Norway), an area contaminated by metals and organic xenobiotics of industrial origin (Follum \& Moe 1988), and from NIVA mesocosm facilities at Solbergstrand (near Oslo), where a contaminant gradient had been simulated in experimental basins (Bakke et al. 1988). Briefly, the M. edulis were sampled according to the following schedule.

The 4 field sites in Langesundfjord (designated Sites 1 to 4) were chosen to represent a gradient of increasing water contamination towards the contaminant source. Tissue levels for selected contaminants such as polycyclic aromatic hydrocarbons (PAHs), polychlorinated biphenyls (PCBs) and trace metals were measured by Klungsøyr et al. (1988) and Abdullah \& Steffenak (1988); see also Appendix 1.

The 4 experimental basins were dosed for $15 \mathrm{wk}$ from April 1986 with differing concentrations of the same mixture of diesel oil (water accommodated fraction) and copper (C: control, L: low, M: medium and $\mathrm{H}$ high dose), see Bakke et al. (1988). High dose levels were chosen to impact the organisms strongly, while C, 
Table 1. Mytilus edulis. Shell length ( $\mathrm{mm}$ ) and body weight $(\mathrm{g}$ ) of individuals from field sites and mesocosm experimental treatments (mean $\pm \mathrm{SE}, n=15$ ). Specimens from Treatment $\mathrm{H}$ were weighed together

\begin{tabular}{|ccc|}
\hline Source & Shell length & Body weight \\
\hline Site & & \\
1 & $46.6 \pm 1.0$ & $4.1 \pm 0.2$ \\
2 & $56.3 \pm 1.1$ & $6.8 \pm 0.5$ \\
3 & $45.4 \pm 1.2$ & $3.5 \pm 0.2$ \\
4 & $46.9 \pm 1.3$ & $3.1 \pm 0.3$ \\
Basin & & \\
C & $54.2 \pm 1.3$ & $7.6 \pm 0.5$ \\
L & $51.4 \pm 2.1$ & $6.1 \pm 0.8$ \\
M & $52.9 \pm 1.3$ & $4.9 \pm 0.4$ \\
CH & $59.0 \pm 2.1$ & $8.9 \pm 0.9$ \\
H & $51.8 \pm 1.3$ & 5.0 \\
\hline
\end{tabular}

I and M conditions were expected to be broadly comparable with the field gradient across Sites 1 to 4 . In addition, a supplementary control sample $(\mathrm{CH})$ was

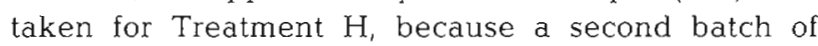
mussels had to be introduced in July following mass mortalities (after $7 \mathrm{wk}$ ) of the original stock of mussels in the $\mathrm{H}$ basin.

Fifteen mussels were sampled from each field site/ experimental condition. Shell length was measured, and after shell opening and gross examination, the body was removed and weighed (Table 1). The mussels were then fixed for histological examination in Davidson's fluid, for $24 \mathrm{~h}$, and kept in $10 \%$ formalin until processing. Two portions of tissue per mussel were

Table 2. Mytilus edulis. Parasitism by larval trematodes in mussels from the field sites and mesocosm experimental treatments. Frequency number of mussels parasitized ( $n=15)$; density: mean number per histological section of parasitized mussel

\begin{tabular}{|c|c|c|c|}
\hline \multirow[t]{2}{*}{ Source } & \multicolumn{2}{|c|}{ Metacercariae } & \multirow{2}{*}{$\begin{array}{l}\text { Sporocysts } \\
\text { Frequency }\end{array}$} \\
\hline & Frequency & Density & \\
\hline \multicolumn{4}{|l|}{ Site } \\
\hline 1 & 14 & 8.6 & 2 \\
\hline 2 & $1 \cdots$ & 1.0 & 0 \\
\hline 3 & $0^{\cdots}$ & - & 0 \\
\hline 4 & $0^{\cdots}$ & - & 0 \\
\hline \multicolumn{4}{|l|}{ Basin } \\
\hline$C$ & 1 & 1.0 & 0 \\
\hline $\mathrm{L}$ & 1 & 1.0 & 0 \\
\hline M & 2 & 1.0 & 0 \\
\hline $\mathrm{CH}$ & $10^{\cdots}$ & 7.2 & 0 \\
\hline $\mathrm{H}$ & $14 \cdots$ & 5.9 & 2 \\
\hline \multicolumn{4}{|c|}{$\begin{array}{l}\text { Significant difference from Site } 1 \text { (field sites) and from } \\
\text { Treatment } C \text { (mesocosm basins) indicated by } \cdots p<0.01 \text {, } \\
\cdots p<0.001 \text {, Fisher s exact test }\end{array}$} \\
\hline
\end{tabular}

embedded in paraffin wax, comprising a section across the digestive gland and a longitudinal section through the foot. Tissue sections $5 \mu \mathrm{m}$ thick were stained with a modified Mallory's trichrome (Pauley 1967). The alternative Nile blue method of Lillie (Pearse 1972) was used to demonstrate lipofuscins. Slides were then examined for parasitic infestations and other pathological signs, including cellular inflammatory response (as defined by Cheng 1985), degeneration, healing processes, regeneration and neoplasia.

Statistical analysis involved the use of the Fisher exact probability test to compare incidences at the polluted sites with the reference site (1), and to compare mesocosm treatments with the control (C). The $t$ test was used to compare tissue weights between sites (or between experimental treatments) but only when mean shell length was essentially the same for the 2 groups being compared.

\section{RESULTS}

\section{Gross pathology}

No gross changes other than those induced by gonad development in the mantle were noticed in any Mytilus edulis. In field mussels, tissue weight was significantly decreased at Site 4 in comparison with Site $1(p<0.05$, Table 1). Likewise, from the experimental exposures, mussel tissue weight was significantly decreased in Treatment $M$ compared with Treatment $C(p<0.01)$.

\section{Parasitism}

Samples from both field and experimental conditions were parasitized by larval trematodes. Most of these were metacercariae with a thick wall (Fig. 2a), encysted in the interstitial tissues mainly around the digestive gland and in the mantle. A second and less abundant type of metacercarial larva, identified as an echinostome trematode, was found encysted in the foot and was frequently encapsulated by haemocytes. Sporocysts containing cercariae were observed in a few specimens (Fig. 2a). No other type of parasite was detected in a total of 135 mussels.

Frequencies and densities of parasites varied widely among the samples, from 0 to $93 \%$ (Table 2). Heavily parasitized mussels occurred in Experimental treatments $\mathrm{H}, \mathrm{CH}$ and at Field site 1, while mussels at Field sites 2, 3 and 4, and in Experimental treatments $C_{\text {, }} \mathrm{L}$ and $M$ were (at worst) lightly parasitized. These results provide no evidence of an association between the degree of parasitic infestation and contaminant gradients 
Table 3. Mytilus edulis. Incidence of main histological characteristics and pathological changes (not related to parasitism) in individuals from field sites and mesocosm experimental treatments $(\%, n=15)$. (Interst: interstitial tissues, muscles and foot; Circ: circulatory system; CBC: clusters of brown cells; DEG: degenerative changes; CIR: cellular inflammatory response; BCL: brown coloured lysosomes; G: granulocytomas; HA: haemocyte aggregates; subscripts: $M$, males; F, females

\begin{tabular}{|c|c|c|c|c|c|c|c|c|c|c|c|c|c|c|c|c|c|c|c|}
\hline \multirow{3}{*}{$\begin{array}{l}\text { Source } \\
\text { Site }\end{array}$} & \multicolumn{3}{|c|}{ Stomach } & \multicolumn{3}{|c|}{ Intestine } & \multirow{2}{*}{$\begin{array}{l}\text { Ducts } \\
\text { DEG }\end{array}$} & \multicolumn{2}{|c|}{ Tubules } & \multicolumn{2}{|c|}{ Kidney } & \multicolumn{2}{|c|}{ Interst } & \multirow{2}{*}{$\begin{array}{l}\text { Circ } \\
\text { HA }\end{array}$} & \multirow{2}{*}{$\begin{array}{l}\text { Gill } \\
\text { DEG }\end{array}$} & \multirow{2}{*}{\multicolumn{4}{|c|}{$\begin{array}{c}\text { Gonad } \\
\mathrm{DEG}_{\mathrm{F}} \mathrm{CIR}_{\mathrm{F}} \mathrm{ClR}_{\mathrm{M}} \mathrm{C}\end{array}$}} \\
\hline & $\mathrm{CBC}$ & DEG & $\mathrm{CIR}$ & $\mathrm{CBC}$ & DEG & CIR & & $\mathrm{BCL}$ & DEC & $C B C$ & DEG & CIR & $G$ & & & & & & \\
\hline & & & & & & & & & & & & & & & & & & & \\
\hline 1 & 73 & 13 & 0 & 13 & 0 & 0 & 27 & 87 & 0 & 8 & 0 & 13 & 13 & 0 & 0 & 20 & 0 & 0 & 0 \\
\hline 2 & 100 & 7 & 0 & $60^{\cdots} \cdot$ & 7 & 0 & 0 & 60 & 0 & 8 & 8 & 0 & 40 & 0 & 0 & 50 & 33 & 20 & 0 \\
\hline 3 & 53 & 0 & 7 & 20 & 0 & 7 & 0 & $40^{\circ}$ & 0 & 0 & 0 & 0 & $47^{\circ}$ & 0 & 0 & 33 & 0 & 0 & 7 \\
\hline 4 & 38 & 0 & 0 & $47^{\circ}$ & 7 & 0 & 0 & $13^{\circ}$ & 0 & 11 & 0 & 0 & 33 & 0 & 0 & 100 & 0 & 0 & 0 \\
\hline \multicolumn{20}{|l|}{ Basin } \\
\hline C & 67 & 53 & 0 & 33 & 27 & 0 & 0 & 0 & 7 & 0 & 0 & 0 & 0 & 0 & 0 & 71 & 0 & 0 & 0 \\
\hline $\mathrm{L}$ & 93 & $7 \cdots$ & 7 & 13 & 0 & 13 & 7 & 0 & 20 & 0 & 0 & 0 & 0 & 0 & 0 & 80 & 0 & 0 & 0 \\
\hline$M$ & 60 & $15^{\circ}$ & 0 & 47 & 0 & 7 & 0 & 0 & 13 & 0 & 0 & 0 & 0 & 0 & 0 & 53 & 0 & 0 & 0 \\
\hline $\mathrm{H}$ & 80 & 20 & 33 & 27 & 33 & 40 & 60 & 0 & $60^{\cdots}$ & 0 & $33^{\circ}$ & 0 & 0 & 33 & $100 \cdots$ & 75 & 0 & 0 & 0 \\
\hline
\end{tabular}

Significant difference from appropriate reference site (1) or mesocosm control (C) indicated by $p<0.05, \cdots p<0.01, \cdots p<0.001$ Fisher's exact test

In every sample, haemocyte aggregates were present in interstitial tissues of the digestive gland and the gonad, around dead metazoans, probably copepods. Since this phenomenon corresponds to a resorption process of foreign material, such features were not considered as true incidences of parasitism.

\section{Histopathology \\ Field samples}

Several pathological changes were observed at every field site (Table 3), and no sample was considered as being in good health. At Site 4 , however, only $67 \%$ of the mussels exhibited pathological changes. Degenera- tive features (atrophy and necrosis) were infrequently noted in the epithelium of the kidney. In the digestive tract, clusters of brown cells (CBC) were scattered throughout the epithelium of the stomach and intestine, with irregular but often high frequencies. These epithelia were also the site for high frequencies of focal inflammation (CIR) and degenerative processes (DEG). In mussels from every site, the epithelium of the digestive tubules showed a conspicuous histological feature after staining with the trichrome technique: the apical cytoplasm of the digestive cells was filled with small and regular brown granules, which were identified as late secondary or tertiary lysosomes (Fig. 1a). After staining with the Nile blue method, these granules had a greenish colour indicative of lipofuscin content, while secondary lysosomes of normal appearance (in other

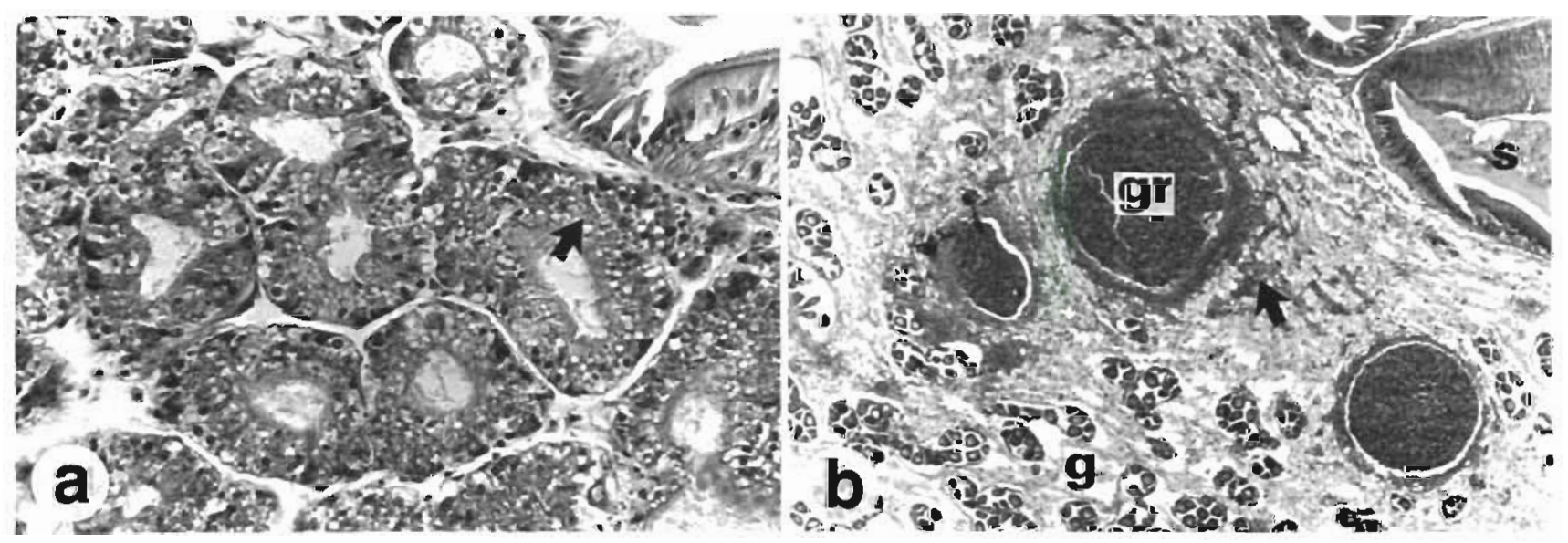

Fig. 1. Mytilus edulis. Histopathology of mussels from field sites: (a) Epithelial cells of digestive gland tubules (Site 2), containing numerous brown coloured lysosomes (arrow) - the other cellular components have a normal appearance; $\times 260 ;(b)$ large granulocytomas (gr) surrounded by haemocytic infiltration (arrow) in a mussel from Site 3; g: gonad, s: stomach; $\times 50$ 

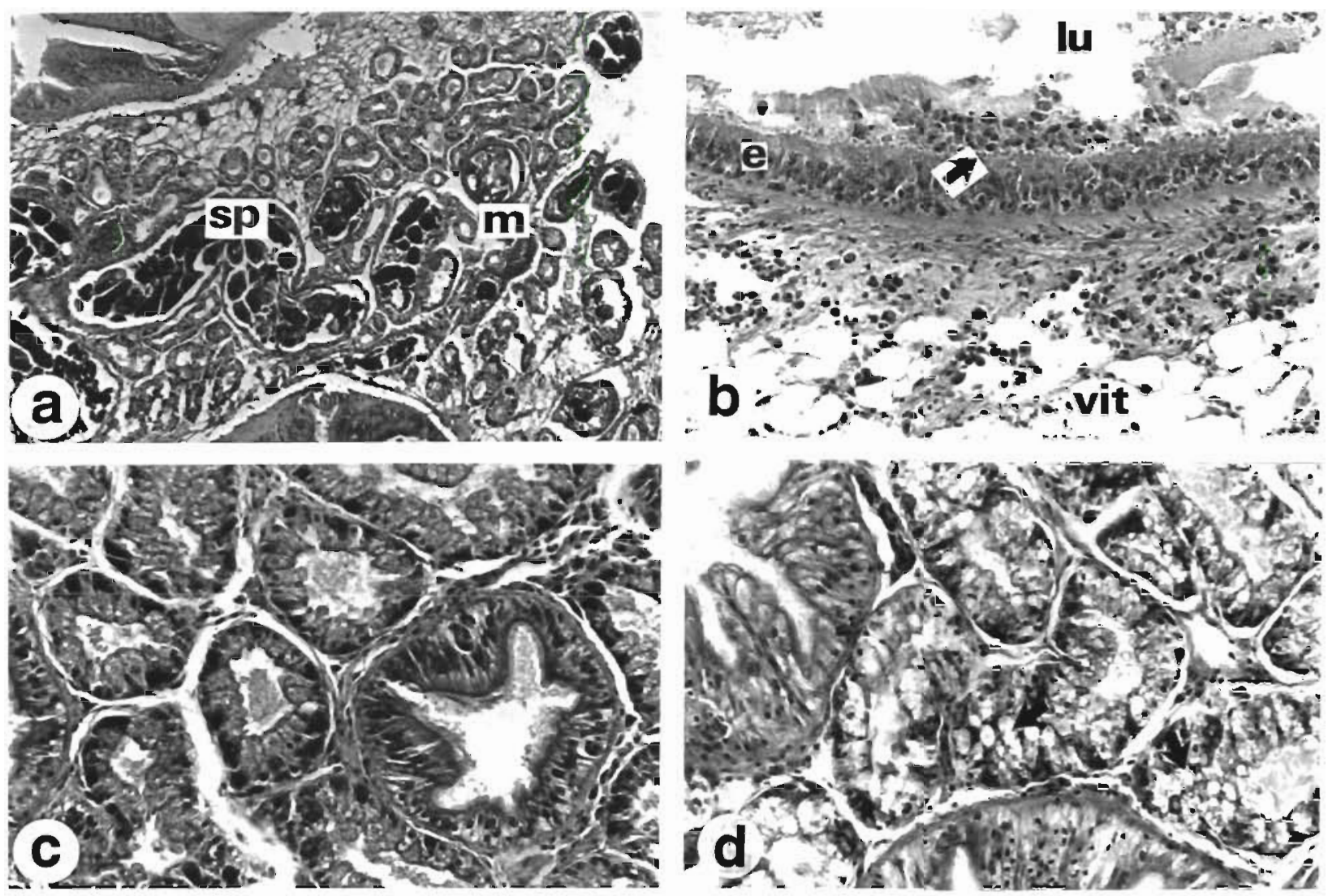

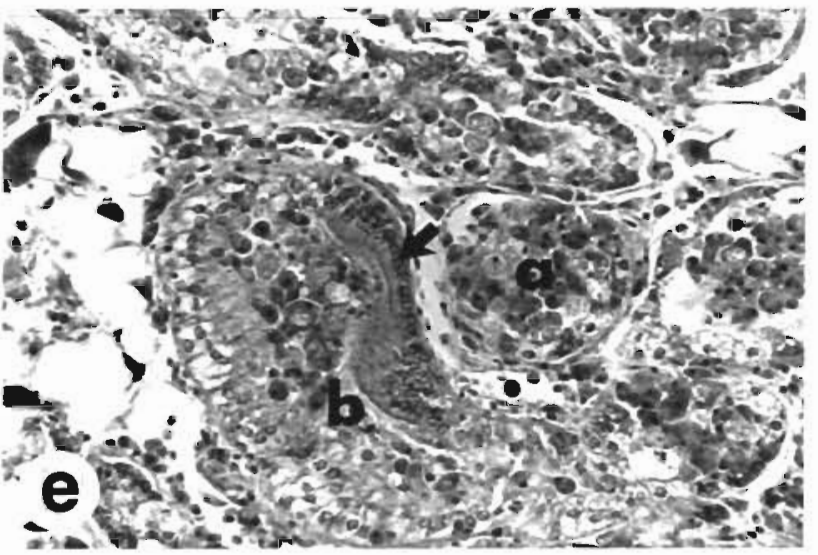

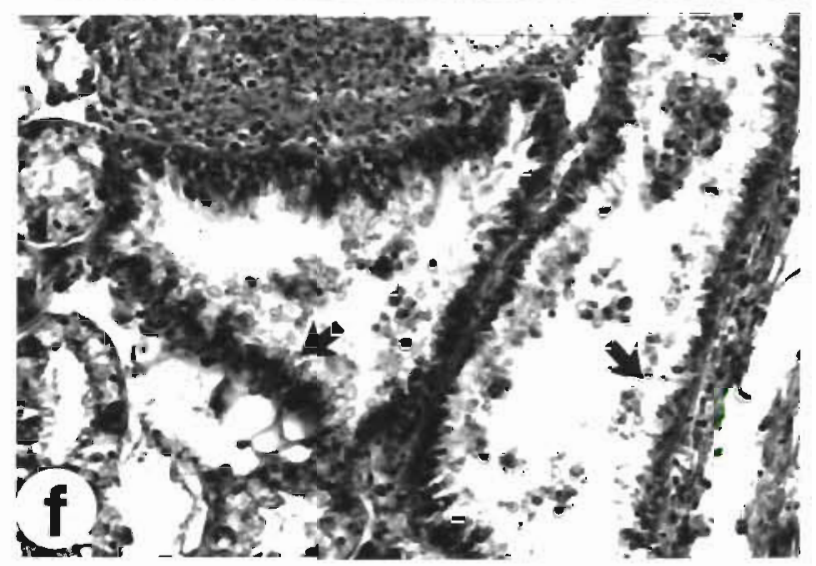

10
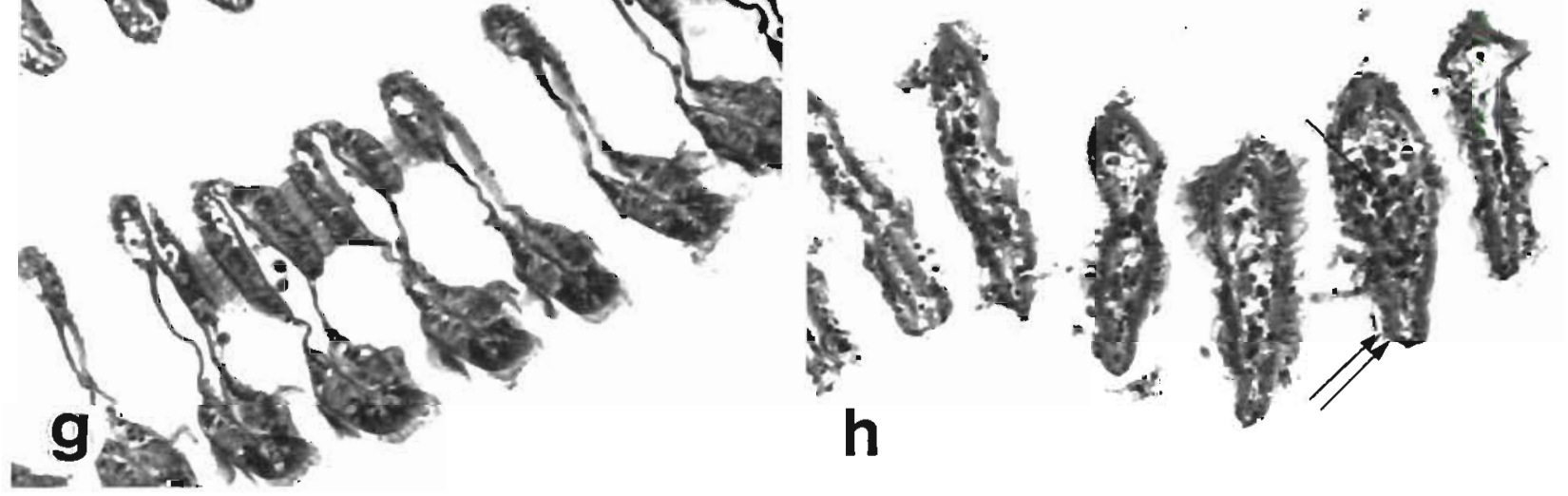
mussels) were stained light blue. The brown colour of the lysosomes resulting from the trichrome technique may have been enhanced by a component of the staining mixture. Other components of digestive cells containing brown lysosomes had a normal appearance (Fig. 1a). The incidence of these 'brown coloured' lysosomes decreased steadily from Site $1(87 \%)$ to Site $4(13 \%)$, and there was a significant negative correlation between incidence of these lysosomes and total PAH concentration $(r=-0.991$, $\mathrm{df}=2, p<0.01)$.

The other striking feature was the presence in every site of granulocytomas (according to Lowe \& Moore 1979) scattered in the interstitial tissues (Fig. 1b). These latter occurred in 13 to $47 \%$ of the animals. High frequencies were found at Sites 2, 3 and 4, though Site 3 was the only one with significantly higher incidence than Site 1. The mussels showed variable reproductive condition, that is, some specimens were fully mature, male or female, while others had empty follicles. Areas of necrosis were observed in mature female follicles, affecting every mussel at Site 4 and up to $50 \%$ of the mussels at the other sites.

\section{Experimental samples}

Conspicuous histological features were noted in the digestive system of mussels from every treatment (Table 3). Clusters of brown cells were scattered in stomach and intestinal epithelia, with a frequency and a density obviously not related to the exposure gradient. Other epithelial alterations, mostly inflammation and necrosis of epithelial cells, were frequent in Treatment $\mathrm{H}$ (Fig. 2b) and in Treatment $\mathrm{C}$. In the digestive gland, no 'brown coloured' lysosomes were observed, but the epithelium of the tubules showed conspicuous degenerative changes (loss of cohesion and cytolysis of digestive cells, to varying degrees), which were more frequent in Treatment $\mathrm{H}$ (Fig. 2d). In these mussels, a phenomenon of haemocytic diapedesis was noted and several specimens had a mixture of haemocytes and cellular fragments replacing the epithelium (Fig. 2e). The ducts were also affected and showed focal or systemic vacuolization or desquamation of epithelial cells, except in the ciliated groove (Fig. 2e). Slight to severe degenerative changes were noted in the kidney epithelium in $33 \%$ of the mussels from Treatment $\mathrm{H}$
(Fig. 2f). Mussels from this treatment also showed poor gill condition. Frontal cilia were missing, and filament lumens were swollen and filled with haemocytes (Fig. 2h). In many cases, haemocytes were also observed outide the lumen, probably resulting from diapedesis through the epithelium. A high degree of gonad maturity occurred in mussels from the experimental exposures and degenerative processes were observed in every treatment, with a similar frequency to those occurring in the field, except for Treatment $\mathrm{H}$ where males were also affected.

\section{DISCUSSION}

In Mytilus edulis parasitism by larval trematodes has been demonstrated and quantified by histological analysis. Since neither the frequency nor the densities of parasitism could be correlated with the contaminant gradients, this parasitism does not appear to be a good descriptor of biological effect. For field mussels, the very high frequency found at the less-polluted reference site implies that biotic factors must also be considered to explain this pattern of parasitism.

Systematic microscopical observation of tissues has shown various abnormal features in organs from field and experimental mussels. While some were not representative of environmental pollution, others were recognized as true pathological changes, which corresponded mainly to inflammatory and degenerative processes, but never to neoplastic processes.

In field mussels, the epithelium of the digestive tract was the site for focal inflammation and necrosis. Brown coloured secondary and tertiary lysosomes were a conspicuous feature in the digestive cells of the tubules. The incidence of these lysosomes was variable, although their appearance was consistent at the cellular level. In marine molluscs, lysosomes are known to be associated with xenobiotic-induced cellular pathology, disturbing their structure and function (Moore $1982,1985)$. The analysis of these lysosomal alterations is the aim of the contributions to this Special MEPS Volume by Moore (1988) and Lowe (1988). However, the brown coloured lysosomes reported here are not indicative of a pathological change; rather, bearing in mind that their incidence was inversely correlated to total PAH concentration at the field sites, it is sug-

Fig. 2. Mytilus edulis. Histopathology of mussels from the mesocosm experiment. (a) Larval trematodes in digestive gland (Treatment $\mathrm{H}$ ) - a metacercaria $(\mathrm{m}$ ) with a thick wall and sporocysts (sp) containing cercariae, $\times 60$; (b) epithelium (e) of stomach showing haemocytic infiltration associated with necrosis (arrow); lu: lumen, vit: vesicular interstitial tissue, $\times 200$; (c) normal appearance of digestive gland tubules (Treatment C), $\times 250$; (d) poor histological condition of digestive tubule epithelium (Treatment $H$ ), showing extensive vacuolization in cells (arrows), $\times 250$; (e) severe haemocytic infiltration (Treatment $H$ ) in and around digestive gland tubules (a) and ducts (b), arrow: ciliated groove, $\times 250$; (f) kidney (Treatment H) showing severe necrosis of the epithelium (arrows), $\times 200 ;(\mathrm{g})$ normal appearance of gill filaments (Treatment $\mathrm{C}$ ), $\times 230$; (h) swollen gill filaments

(Treatment $\mathrm{H}$ ) filled with haemocytes (single arrow), front cilia of epithelial border are also absent (double arrow), $\times 230$ 
gested that a high incidence reflects the normal condition. The most obvious pathological condition consisted of granulocytomas, which occurred throughout the interstitial tissues of numerous field mussels. Lowe \& Moore (1979) have suggested a relationship between this particular type of inflammatory response and chronic pollution, while Rasmussen et al. (1983b) have induced a similar pathology in mussels after chronic chemical exposure. It seems probable therefore that the occurrence of granulocytomas in the Langesundfjord mussels is a consequence of chronic exposure to contaminants.

In the experimental treatments, specimens exposed to the highest concentrations of hydrocarbons and copper had severe degenerative changes in the epithelia of the digestive gland. The appearance of such an ultimate cellular disturbance is in agreement with the hypothesis of an autolytic process, as a consequence of full lysosomal destabilization (Moore 1985). Necrosis and infiltration of severely damaged tubules by haemocytes have been reported by Rasmussen (1982) and Rasmussen et al. (1983a, b) in mussels challenged with $\mathrm{N}$-nitroso compounds. Couch (1985) described atrophic epithelium sloughing of cells and necrosis as an ultimate tubular degeneration, in oysters from contaminated estuaries. The findings of Rasmussen suggest that chemically-induced injuries are implicated in the formation of such lesions. The other striking tissue lesion noted in these mussels involved the gills, which exhibited morphological changes in their filaments and severe disturbance of the ciliated epithelial cells, when compared to mussels from control and low exposure treatments. Similar lesions have been reported in mussels exposed to sublethal thermal stress (Gonzales \& Yevich 1976), to N-nitrosodimethylamine (Rasmussen 1982) and to copper and cadmium exposure (Sunila 1986). This apparent non-specificity indicates that the gills are particularly sensitive organs in mussels.

It is clearly important to assess the histopathological responses of Mytilus edulis in relation to the measured contaminant levels. Briefly, the chemical analysis of mussel tissues revealed an increasing content for PAHs and PCBs from Site 1 to Site 4, as well as for copper from Treatment $\mathrm{C}$ to Treatment $\mathrm{H}$ and for PAHs from Treatment $C$ to Treatment $M$. In field mussels, the granulocytomas were very frequent in the most contaminated sites. Their occurrence was significantly higher at Site 3 than the reference site, and the incidences at Sites 2, 3 and 4 were not significantly different from each other The level of quantification (presence or absence in $n=15$ mussels) is insufficient to expect to demonstrate a detailed 'dose-response' relationship. Nonetheless, the increased prevalence of granulocytomas at the contaminated sites corroborates the results of Lowe \& Moore (1979) with mussels from British coasts, and lends support to the postulate that granulocytomas can be used as an index of haemocytic response to aquatic contamination. Conversely, pathological changes in epithelia of the digestive tract occurred infrequently and irregularly among the 4 sites, and this could be interpreted as a response to unidentified deleterious factors. In the experimental treatments, histopathological response could not be correlated to dosing levels of contaminants, with the exception of the $\mathrm{H}$ treatment, for which the mussels displayed severe pathological changes involving the epithelia of the digestive system, gills and kidney. These obviously reflected a poor health condition, presumably induced by the xenobiotics. Furthermore, the pathology observed in $\mathrm{H}$ mussels, together with that reported for experimental treatments by Rasmussen et al. (1983a,b, 1985), confirm that the digestive gland is a target tissue for xenobiotic effects (Sindermann 1980).

When comparing results from Mytilus edulis in the field and experimental studies, it appears that, although total PAH tissue concentrations span similar ranges, the response in terms of pathological changes is not the same, as no granulocytomas were detected in the experimental treatments. However, chemical analysis (Klungsøyr et al. 1988) revealed that the composition of the PAHs differed between field and experimental conditions, with higher molecular weight compounds dominating in the field and lower molecular weight compounds in the experimental exposures. This was probably the major contnbutory factor to the differences in the observed pathology, although the experimental results may have been affected by the starved condition of the mussels (Lowe 1988), and the field results by possible interactive effects of contaminants.

In conclusion, this study has demonstrated that, in field mussels, non-parasitic tissue abnormalities were related to chemical contamination. Similar pathological effects were not generally induced in the experimental treatments, though Mytilus edulis from the highest dose treatment exhibited a clear response to contaminants. In an attempt to select pathological indicators of pollution, this histological analysis of tissue modifications may not entirely satisfy general criteria required in monitoring programmes, since it is difficult to define a smooth dose-response relation based only on presence or absence of histopathological features. This underlines the need for standard histology to be undertaken parallel to other types of cellular investigations, such as quantitative histology and cell biochemistry However, standard histology has shown its utility here for characterizing tissue effects of xenobiotic exposure that can be compared directly with other data sets. 
Acknowledgements. The author thanks the International Council for the Exploration of the Sea for funding his participation at the GEEP Workshop, and Dr M. N. Moore for critically reviewing the manuscript and providing the statistical analysis of the data.

\section{LITERATURE CITED}

Abdullah, M. I., Steftenak, I. (1988). The GEEP Workshop: trace metal analyses. Mar. Ecol. Prog. Ser. 46: 27-30

Bakke, T., Follum, O. A., Moe, K. A., Sorensen, K. (1988). The GEEP Workshop: mesocosm exposures. Mar. Ecol. Prog. Ser. 46: $13-18$

Balouet, G., Poder, M. (1981). Effets biologiques de la pollution par les hydrocarbures de l'Amoco-Cadiz sur l'ostréiculture en Bretagne Nord. In: Amoco-Cadiz. Conséquences diune pollution accidentelle par les hydrocarbures. CNEXO, Paris, p. 703-713

Cheng, T C. (1985). Evidence for molecular specificities involved in molluscan inflammation. In: Cheng, T.C. (ed.) Comparative pathobiology, Vol. 8. Plenum Press, New York, p. 129-142

Couch, J. A. (1985). Prospective study of infectious and noninfectious diseases in oysters and fishes in three Gulf of Mexico estuaries. Dis. aquat. Org. 1: 59-82

Follum, O. A., Moe, K. A. (1988). The GEEP Workshop: field sampling. Mar. Ecol. Prog. Ser. 46: 7-12

Gonzales, J. G., Yevich, P. (1976). Responses of an estuarine population of the blue mussel Mytilus edulis to heated water from a steam generating plant. Mar. Biol. 34: $177-189$

Klungsøyr, J., Wilhelmsen, S., Westrheim, K., Saetvedt, E., Palmork, K. H. (1988). The GEEP Workshop: organic chemical analyses. Mar. Ecol. Prog. Ser. 46: 19-26

Lowe, D. M. (1988). Alterations in cellular structure of Mytilus edulis resulting from exposure to environmental contaminants under field and experimental conditions. Mar. Ecol. Prog. Ser. 46: $91-100$

Lowe, D. M., Moore, M. N. (1979). The cytology and occurrence of granulocytomas in mussels. Mar. Pollut. Bull. 10 $137-141$

Moore, M. N. (1982). Lysosomes and environmental stress. Mar. Pollut. Bull. 13: 42-43
Moore, M. N. (1985). Cellular responses to pollutants. Mar Pollut. Bull. 16: 134-139

Moore, M. N. (1988). Cytochemical responses of the lysosomal system and NADPH-ferrihemoprotein reductase in molluscan digestive cells to environmental and experimental exposure to xenobiotics. Mar Ecol. Prog. Ser. 46: 81-89

Pauley, G. B. (1967). A modification of Mallory's trichrome anilin blue collagen stain for oyster tissue. J. invert. Pathol. 9: $268-269$

Pearse, A. G. E. (1972). Histochemistry, theoretical and applied, Vol. 2. Churchill Livingstone, London

Rasmussen, L. (1982). Light microscopical studies on the acute toxic effects of N-nitrosodimethylamine on the marine mussel, Mytilus edulis. J. invert. Pathol. 39:66-80

Rasmussen, L. P. D., Hage, E., Karlog, O. (1983a). Light and electron microscopic studies on the acute and chronic toxic effects of $\mathrm{N}$-nitroso compounds on the marine mussel, Mytilus edulis (L.). I. N-nitrosodimethylamine. Aquat. Toxicol. 3: 285-299

Rasmussen, L. P. D., Hage, E., Karlog, O. (1983b). Light and electron microscopic studies on the acute and chronic toxic effects of $\mathrm{N}$-nitroso compounds on the marine mussel, Mytilus edulis (L.). II. N-methyl-N-nitrosoguanine. Aquat. Toxicol. 3: 301-311

Rasmussen, L. P. D., Hage, E., Karlog, O. (1985). Light and electron microscopic studies on the acute and long-term toxic effects of $\mathrm{N}$-nitrosodipropylamine and $\mathrm{N}$-methylnitrosurea on the marine mussel, Mytilus edulis. Mar. Biol. $85: 55-65$

Sindermann, C. J. (1980). The use of pathological effects of pollutants in marine environmental monitoring programs. Rapp. P.-v. Réun. Cons. int. Explor. Mer 179: 129-134

Sindermann, C. J., Bang, F. B., Christensen, N. O., Dethlefsen, V., Harshbarger, J. C., Mitchell, J. R., Mulcahy, M. F. (1980). The role and value of pathology in pollution effects monitoring programmes, Pathology Panel report. Rapp. P.v. Réun. Cons. int. Explor. Mer 179: 135-151

Sunila, I. (1986). Chronic histopathological effects of shortterm copper and cadmium exposure on the gill of the mussel, Mytilus edulis. J, invert. Pathol. 47: 125-142

Yevich, P. O., Barszcz, C. A. (1976). Histopathology as a monitor for marine pollution; results of the histopathologic examination of the animals collected for the U.S. mussel watch program. Report of the U.S. Environmental Protection Agency 